\title{
Influence of stomatal characteristics on yield and yield attributes of rice
}

\author{
A. K. M. Golam Sarwar*, M. Abdul Karim, and S. M. A. Masud Rana \\ Department of Crop Botany, Bangladesh Agricultural University, Mymensingh-2202, Bangladesh \\ *E-mail: drsarwar@bau.edu.bd
}

\begin{abstract}
Stomatal distribution is found to be an important trait of rice cultivars for increasing yield. A total of six rice cultivars, three from each of inbred and hybrid cultivars, were used to study stomatal distribution on the leaf epidermis and its influence on yield and yield attributing characters of rice during the Boro season. The hybrid cultivars exhibited superiority in respect of number of stomata, length and breadth of stomatal apparatus. They also produced longer panicle, higher number of filled grains panicle ${ }^{-1}$, heavier grains and finally, higher grain yield ha ${ }^{-1}$ than inbreds. The higher grain yield of the hybrid cultivars might be due to higher number of large sized stomata causing higher photosynthetic efficacy, although, they produced relatively lower number of effective tillers hill ${ }^{-1}$.
\end{abstract}

Keywords: Stomatal apparatus, Number and size, Inbred and hybrid cultivars, Boro rice

\section{Introduction}

Rice (Oryza sativa L.) leaf epidermis is composed of long and short cells, stomatal apparatuses and dermal appendages (Metcalfe, 1960). The leaf epidermal features play an important role in distinguishing rice cultivars (Metcalfe, 1960; Sarwar and Ali, 2002). Among these characters, stomatal functioning plays important role for two plant processes, transpiration and photosynthesis. Stomatal conductance for gas diffusion $\left(g_{s}\right)$ and transpiration is closely associated with leaf photosynthesis in rice (Kanemura et al., 2005). Strong indications have been obtained for a major influence of $g_{s}$ on crop growth rate during reproductive period in some crop species (Fischer et al., 1998; Horie et al., 2006). The $\mathrm{g}_{\mathrm{s}}$ is proportional to stomatal density and the average area of stomatal pore, and inversely proportional to length of diffusion pathway determined by depth of stomatal pore (Meidner and Mansfield, 1968). A correlation between leaf photosynthesis and stomatal density was reported for upland and lowland rice varieties grown on flooded soil (Tsunoda and Fukoshima, 1986). Therefore, it is expected that crop yield would be improved by manipulating the morphological characteristics of stomata and gas exchange. The stomatal aperture-related traits have been used as selection criteria for high yield-potential in bread wheat (Codon et al., 2007).

Rice is the staple food for the people of Bangladesh, grown thrice viz. Aus, Aman and Boro seasons, within a year. Among the growing seasons, Boro is the most important both in area coverage and total production of rice (BBS, 2010). The demand of rice is increasing day by day due to fast growing population; on contrary, there is a decreasing trend in availability of cultivable land area due to different anthropogenic and developmental activities. The hybrid rice cultivars, on an average, produced 15 to $30 \%$ higher grain yield than indica inbreds (Yang et al., 2007). Therefore, farmers of Bangladesh are switching over to hybrid cultivars from the modern cultivars to increase the rice production. A lot of research information is available on different traditional and modern rice cultivars (Sarwar and Ali, 1998, 2002; Mondal et al., 2005; Hossain et al., 2007), but research report on comparative study of morphological characters especially leaf epidermal features of different hybrid rice cultivars of Bangladesh is very scanty. Therefore, the present research has been undertaken to study and compare the stomatal distribution on leaf epidermis and its influence on yield and yield attributing characters of some modern and hybrid rice cultivars growing in Boro season of Bangladesh. 


\section{Material and Methods}

The experiment was carried out at the Field Laboratory and Plant Morphology Laboratory, Department of Crop Botany, Bangladesh Agricultural University, Mymensingh, during the Boro season (December 2010 to May 2011). Three hybrids viz. Doyal, Moina and Tia, and three modern (inbreds) viz. BINA dhan7, BRRI dhan28 and BRRI dhan29, rice cultivars were used in this study. All these cultivars of hybrid and inbred rice were collected from Lalteer Seed Company Pvt. Ltd. The experiment was laid out following a randomized complete block design with three replications. The standard procedures for rice cultivation were followed (BRRI, 2010). The yield and yield attributing characters were studied after ripening (at least $80 \%)$ of spikelets.

Matured leaves (third leaf from the top) were collected from the experimental field at the flowering stage and fixed in FAA solution (Sarwar and Ali, 2002). Preparations of epidermal layers were made by scraping of the mature leaf samples (for detail see Sarwar and Ali, 2002). Stomatal features on the leaf epidermis i.e., number, length and breadth of stomatal apparatus, were studied and measured under a compound microscope.

The collected data were analyzed statistically following the analysis of variance (ANOVA) technique and the mean differences were adjudged by Duncan's New Multiple Range Test (DMRT) using the statistical computer package program MSTAT-C.

\section{Results and Discussion}

\section{Stomatal Distribution}

Stomatal features of the studied Boro rice cultivars have been summarized in Table 1 and the basic features of rice leaf epidermis in Fig. 1. There were significant differences in number of stomata, length and breadth of stomatal apparatus among the studied cultivars. In general, hybrids possessed the higher number and the larger stomata than inbreds (Table 1). The cultivar Doyal possessed both the highest number and longest stomatal apparatus (73 and $1.52 \mu \mathrm{m}$, respectively), but the widest stomatal apparatus were observed in Tia $(1.26 \mu \mathrm{m})$. On contrary, the BINA dhan7 possessed the lowest values of all stomatal parameters i.e., number, length and breadth $(50,1.39 \mu \mathrm{m}$ and $0.99 \mu \mathrm{m}$, respectively). These results were supported by the result of Sarwar and Ali (2002). They have reported that number and shape of stomata, occurrence and distribution of dermal appendages to be the character of the cultivar. A negative correlation between stomatal density and stomatal length has been reported (Ohsuni et al., 2007); however, our results did not support this type of relationship (Table 1; Sarwar and Ali, 2002). This might indicate that stomatal size does not vary with the change of stomatal density, when diverse rice cultivars are studied. Stomatal length is related to specific stomatal conductance which is closely related with leaf photosynthesis of rice (Ohsuni et al., 2007) leading to higher yield in hybrid cultivars.

Table 1. Stomatal features of six Boro rice cultivars at the flowering stage. Average value is given

\begin{tabular}{|l|c|c|c|}
\hline Cultivars & $\begin{array}{c}\text { No. of stomata field } \\
\text { (at 450x) }\end{array}$ & $\begin{array}{c}\text { Length of stomatal } \\
\text { apparatus }(\mu \mathrm{m})\end{array}$ & $\begin{array}{c}\text { Breadth of stomatal } \\
\text { apparatus }(\mu \mathrm{m})\end{array}$ \\
\hline BINA dhan7 & $50 \mathrm{c}$ & $1.39 \mathrm{~b}$ & $0.99 \mathrm{c}$ \\
\hline BRRI dhan28 & $54 \mathrm{~b}$ & $1.41 \mathrm{~b}$ & $1.01 \mathrm{c}$ \\
\hline BRRI dhan29 & $56 \mathrm{~b}$ & $1.41 \mathrm{~b}$ & $1.01 \mathrm{c}$ \\
\hline Doyal & $73 \mathrm{a}$ & $1.52 \mathrm{a}$ & $1.17 \mathrm{ab}$ \\
\hline Moina & $68 \mathrm{a}$ & $1.48 \mathrm{ab}$ & $1.08 \mathrm{bc}$ \\
\hline Tia & $72 \mathrm{a}$ & $1.49 \mathrm{ab}$ & $1.26 \mathrm{a}$ \\
\hline LSD $_{(0.05)}$ & 5.04 & 0.10 & 0.13 \\
\hline
\end{tabular}

In a column, same letter (s) do not differ significantly at $\mathrm{P} \leq 0.05$ as per DMRT 


\section{Yield and Yield Attributing Characters}

Apart for the stomatal features, the yield and yield attributing characters are significantly different among the cultivars studied (Table 2). The results revealed that inbreds commonly produced higher number of effective tillers hill ${ }^{-1}$ than hybrids (Table 2). The highest number of effective tiller hill ${ }^{-1}$ was recorded in BINA dhan7 followed by BRRI dhan28 and BRRI dhan29 with the same statistical rank. The lowest number of effective tiller hill ${ }^{-1}$ was recorded in Moina followed by Tia (Table 2). Variation in the production of total number of tillers hill ${ }^{-1}$ might be due to genetic variation, physiological performance, and growth characters of the cultivars under this study. Similar variations among the cultivars have been reported (Huke and Huke, 1997; DRR, 1998).

Table 2. Yield and yield attributes of six Boro rice cultivars. Average value is given

\begin{tabular}{|l|c|c|c|c|c|c|}
\hline Cultivars & $\begin{array}{c}\text { Effective tillers } \\
\text { hill }^{-1}(\text { no. })\end{array}$ & $\begin{array}{c}\text { Panicle length } \\
(\mathrm{cm})\end{array}$ & $\begin{array}{c}\text { Filled grains } \\
\text { panicle }^{-1}(\mathrm{no})\end{array}$ & $\begin{array}{c}1000-\text { grain } \\
\text { weight }(\mathrm{g})\end{array}$ & $\begin{array}{c}\text { Grain yield } \\
\text { hill }^{-1}(\mathrm{~g})\end{array}$ & $\begin{array}{c}\text { Grain yield } \\
\left(\mathrm{t} \mathrm{ha}^{-1}\right)\end{array}$ \\
\hline BINA dhan7 & $15.67 \mathrm{a}$ & $23.89 \mathrm{~b}$ & $112 \mathrm{~d}$ & $22.07 \mathrm{~b}$ & $38.73 \mathrm{e}$ & $4.67 \mathrm{c}$ \\
\hline BRRI dhan28 & $14.50 \mathrm{~b}$ & $22.87 \mathrm{~b}$ & $116 \mathrm{~d}$ & $21.28 \mathrm{~b}$ & $35.79 \mathrm{e}$ & $4.12 \mathrm{~d}$ \\
\hline BRRI dhan29 & $13.73 \mathrm{~b}$ & $23.74 \mathrm{~b}$ & $135 \mathrm{c}$ & $22.84 \mathrm{~b}$ & $42.33 \mathrm{~d}$ & $5.08 \mathrm{c}$ \\
\hline Doyal & $9.22 \mathrm{c}$ & $27.90 \mathrm{a}$ & $200 \mathrm{a}$ & $35.06 \mathrm{a}$ & $64.65 \mathrm{a}$ & $7.30 \mathrm{a}$ \\
\hline Moina & $8.66 \mathrm{c}$ & $26.20 \mathrm{a}$ & $178 \mathrm{~b}$ & $33.25 \mathrm{a}$ & $51.31 \mathrm{c}$ & $6.07 \mathrm{~b}$ \\
\hline Tia & $9.13 \mathrm{c}$ & $26.55 \mathrm{a}$ & $180 \mathrm{~b}$ & $34.18 \mathrm{a}$ & $56.17 \mathrm{~b}$ & $6.40 \mathrm{~b}$ \\
\hline LSD $_{(0.05)}$ & 0.80 & 1.78 & 7.87 & 3.94 & 3.26 & 0.46 \\
\hline
\end{tabular}

In a column, same letter (s) do not differ significantly at $\mathrm{P} \leq 0.05$ as per DMRT

The longest panicle was observed in Doyal followed by Tia and Moina with the same statistical rank. The lowest was recorded in BRRI dhan28 followed by BRRI dhan29 (Table 2). This result was in agreement with the result of Ghosh (2001) who noted that hybrids, in general, gave higher values for panicle length compared to other cultivars. Sarwar and Ali (1998) have reported highly significant and strong positive correlation $(r=0.85)$ between panicle length and grain yield.

Doyal also produced the highest number of filled grains panicle ${ }^{-1}$ followed by Tia and Moina with the same statistical rank (Table 2). On contrary, BINA dhan7 produced the lowest number of filled grains panicle $^{-1}$. Pruneddu and Spanu (2001) reported that the genotypes which produced higher number of grains panicle ${ }^{-1}$ showed higher grain yield. The results obtained from the present study was consistent with the result of Srivastava and Tripathi (1998) who found that the increase in grain yield in hybrid in comparison to local check variety might be attributed to the increased fertile grain panicle ${ }^{-1}$.

Thousand grain weight had also shown a similar trend. The heaviest grains were produced by Doyal followed by Tia and Moina with the same statistical rank. And the lowest 1000-grain weight was produced by BRRI dhan28 followed by BINA dhan7 and BRRI dhan29 (Table 2). There was a significant difference in grain yield hill $^{-1}$. The cultivar Doyal produced the highest grain yield hill ${ }^{-1}$ (Table 2). In contrast, BRRI dhan28 produced the lowest grain yield hill ${ }^{-1}$ followed by BINA dhan7.

The cultivars Doyal also produced the highest grain yield ha ${ }^{-1}$ followed by Tia and Moina with the same statistical rank (Table 2). The higher yield in hybrid cultivars might be due to the production of larger panicle, higher number of filled grains panicle ${ }^{-1}$ and 1000-grain weight (Mondal et al., 2005; JianChang et al., 2006; Yang et al., 2007). In contrast, BRRI dhan28 produced the lowest grain yield preceded by BINA dhan7 (Table 2). This result agreed with the result of Yang et al. (2007). They reported that hybrids, on an average, produced 15 to $30 \%$ greater grain yield than indica inbreds. 


\section{Stomatal features and grain yield}

The grain yield showed significant and positive correlation with number, length and breadth of stomatal apparatus (Figs $2 \mathrm{a}-\mathrm{c}$ ). These types of significant correlations between stomatal features and grain yield were also observed and reported by many researchers in different crops (Arminian et al., 2008; Yousufzai et al., 2009; Aminian et al., 2010; Limochi and Eskandari, 2013; and older references therein). Buckley (2005) reported that numbers of stomata are related with photosynthetic activities. Chandra and Das (2000) observed that the stomatal area had significant effect on photosynthesis in rice. Leaves with larger stomata had higher photosynthesis rate than the leaves with smaller stomata. They also reported that broader leaves had larger stomata than narrow leaves. Maherali et al. (2002) stated that broader stomata can also facilitate $\mathrm{CO}_{2}$ diffusion into the leaf, because its conductance is proportional to the square of the effective radius of the stomatal pore, leading to increased gas diffusion $\left(g_{s}\right)$. In rice, grain yield had its maximum correlation with stomata area $(r=0.405)$ suggesting that this property can be used as an important factor in breeding programs for improving grain yield (Limochi and Eskandari, 2013). The number and size of stomata to be directly related with different plant physiological processes e.g., photosynthesis and the higher photosynthetic activities are related to more yield in hybrids (Tables 1 and 2).

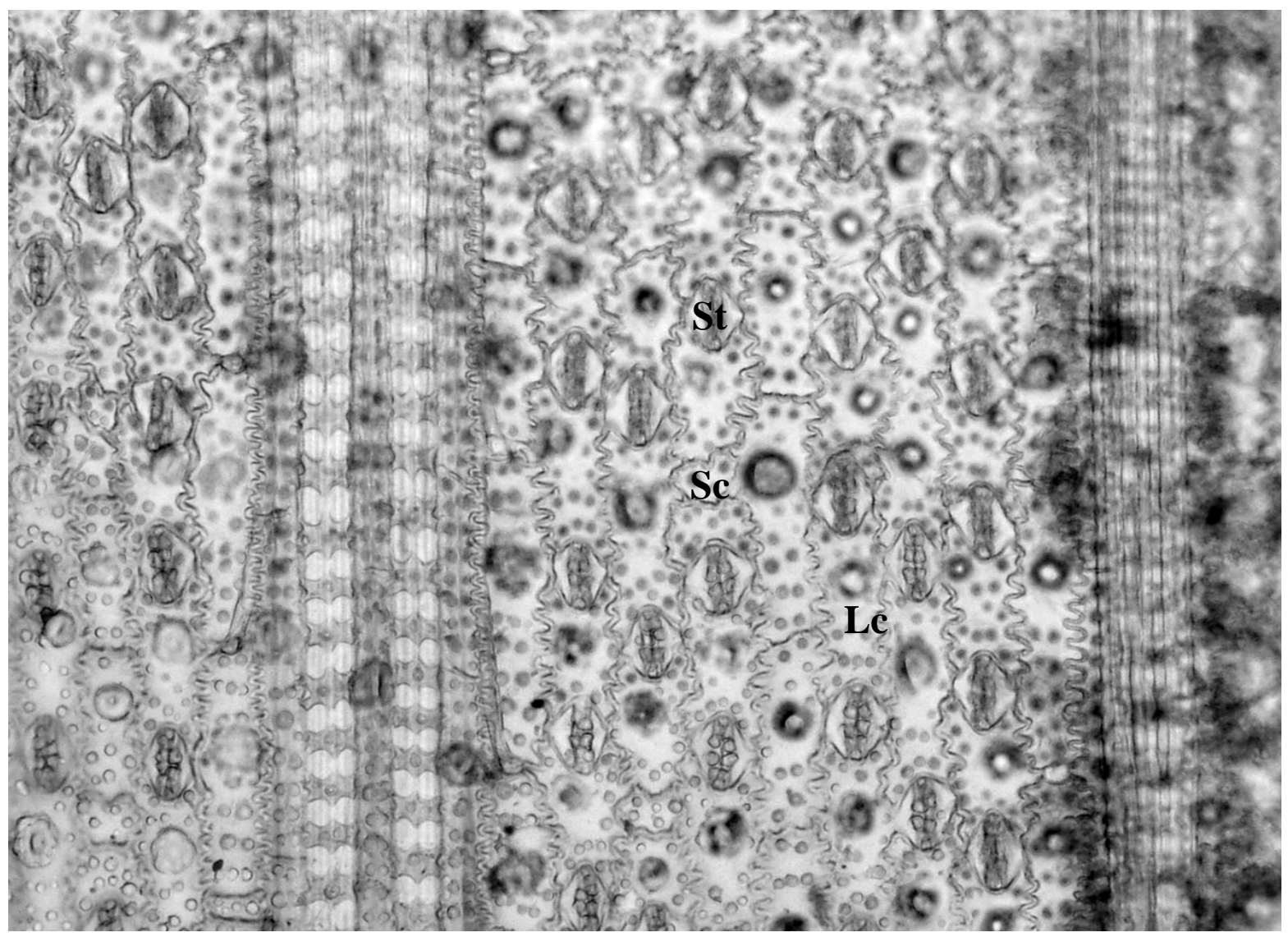

Fig. 1. Basic features of rice (cv. Doyal) leaf epidermis. St Stomata with guard cells, Sc Short cell, Lc Long cell 


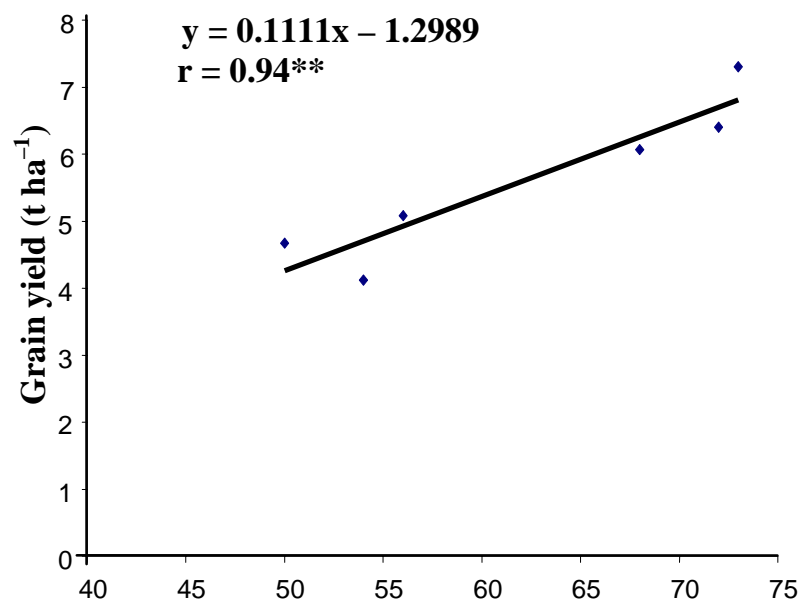

No. of stomata field ${ }^{-1}$

a.

(450x)

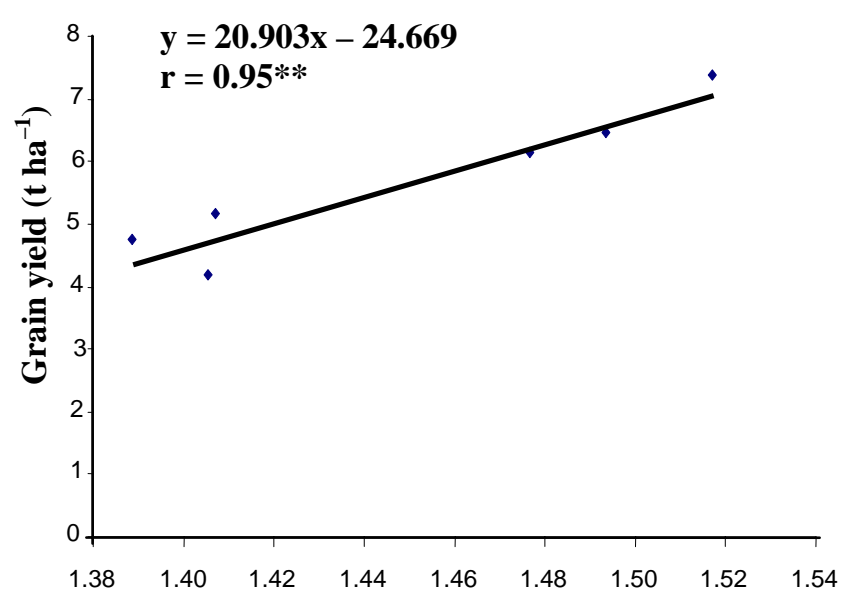

b.
Length of stomatal

apparatus $(\mu \mathrm{m})$

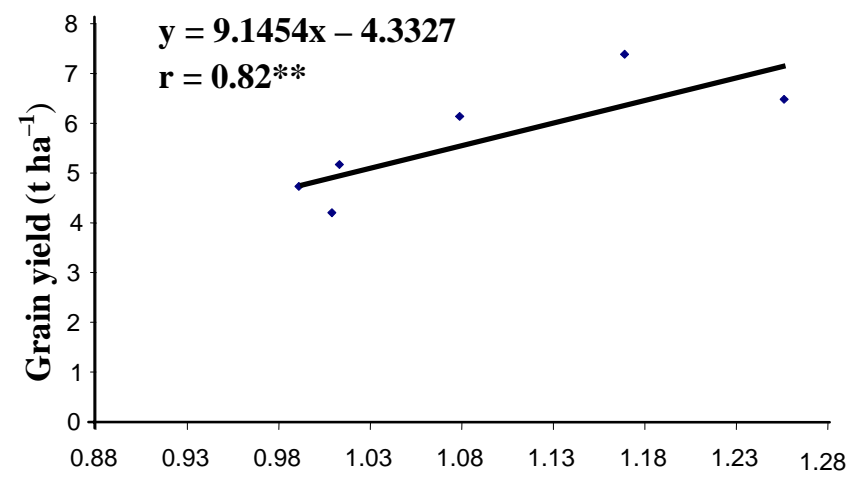

c.

Breadth of stomatal apparatus $(\mu \mathrm{m})$

Fig. 2. Correlation coefficient indicates the strength of a linear relationship between (a) number of stomata and grain yield, (b) length of stomatal apparatus and grain yield, and (c) breadth of stomatal apparatus and grain yield

It might be concluded that the stomatal characteristics viz. number, length and breadth, play an important role for higher yield in hybrid cultivars, though, they produce relatively lower number of effective tillers hill 1 . These stomatal features and the number of effective tillers in hybrids might be useful for inclusion in the future breeding programmes of rice for higher yield in Bangladesh.

\section{References}

Aminian, R., Mohammadi, S., Hoshmand S.A. and Khodambashi, M. 2010. The genetic analysis of stomatal frequency and size, stomatal conductance, photosynthetic rate and yield in wheat (Triticum aestivum L.) using substitution lines series. Wheat Inf. Serv., 110: 25-34.

Arminian, A., Houshmand, S., Knox, R.E. and Shiran, B. 2008. Stomatal characteristics, heritability and their relation to grain yield in a double haploid bred wheat population. In: Appels, R., Eastwood, R., Lagudah, E., Langridge, P., Mackay, M., Mclntyre, L. and Sharp, P. (eds.). Proc. 11th Int. Wheat Gen. Symp., 24 - 29 August 2008, Brisbane, Australia. 2: 638-640. 
BBS. 2010. Statistical Year Book of Bangladesh. Bangladesh Bureau of Statistics (BBS), Stat. Div., Min. Plan., Govt. Peop. Repub. Bangladesh, Dhaka.

BRRI. 2010. Modern Rice Cultivation (in Bangla). $15^{\text {th }}$ ed., Bangladesh Rice Research Institute (BRRI), Gazipur. p. 1-47.

Buckley, T.N. 2005. The control of stomata by water balance. New Phytol., 168: 275-292.

Chandra, K. and Das, A.K. 2000. Correlation and interaction of physiological parameters in rice under rainfed transplanted condition. J. Crop Res. Assam Agric. Univ., 19: 251-254.

Condon, A.G., Reynolds, M.P., Rebetzke, G.J., Van Ginkel, M., Richards, R.A. and Farquhar, G.D. 2007. Using stomatal aperturerelated traits to select for high yield potential in bread wheat. In: H.T. Buck et al. (eds.), Wheat Production in Stressed Environments. p. 617-624.

DRR. 1998. Progress Report 1997. Vol. 3: Agronomy, Soil Science and Physiology. Directorate of Rice Research (DRR), All India Coord. Rice Improv. Prog., India.

Fischer, R.A., Ress, D., Sayre, K.D., Lu, Z.M., Condon, A.G. and Saavedra, A.L. 1998. Wheat yield progress associated with higher stomatal conductance and photosynthetic rate, and cooler canopies. Crop Sci., 38: 1467-1475.

Ghosh, M. 2001. Performance of hybrid and high-yielding rice varieties in Teraj region of West Bengal. J. Int. Academic., 5: 578-581.

Horie, T.T., Matsuura, S., Takai, T., Kuwasaki, K., Ohsumi, A. and Shiraiwa, T. 2006. Genotypic difference in canopy diffusive conductance by a new remote-sensing method and association with the difference in rice yield potential. Plant Cell Environ., 29: 653-660.

Hossain, M.N., Uddin, M.R., Tabassum, N. and Jannat, R. 2007. Yield performance of Boro rice as influenced by nitrogen and spacing. Bangladesh J. Crop Sci., 18: 99-104.

Huke, R.E. and Huke, E.H. 1997. Rice Area by Type of Culture: South, Southeast, and East Asia; A Revised and Updated Database. Int. Rice Res. Inst., Los Baños, Philippines.

JianChang, Y.D., Yong, W., ChangFu, L., LiJun, W., ZhiQin, Z. and QingSen. 2006. Growth and development characteristics of super-high-yielding mid-season japonica rice. Sci. Agric. Sinica, 39: 1336-1345.

Kanemura, T., Homma, K., Ohsumi, A., Narisu, Hosie, T., Shiraiwa, T., Ebana, K., Uga, Y., Kojima, Y. and Fukuoka, S. 2005. Analysis of genetic variability in yield-related traits of rice using global care collection. II. Leaf photosynthetic rate and associated factors. Jpn. J. Crop Sci., 74 (ex. 2): 238-239.

Limochi, K. and Eskandari, H. 2013. Effect of planting date on the performance of flag leaf stomata and grain yield of rice cultivars. Int. J. Agron. Plant Prod., 4: 769-773.

Maherali, H., Reid. C.D., Polley, H.W., Johnson, H.B. and Jachson R.B. 2002. Stomatal acclimation over a subambient to elevated $\mathrm{CO}_{2}$ gradient in $\mathrm{C}_{3} / \mathrm{C}_{4}$ grassland. Plant Cell Environ., 25: 557-566.

Meidner, H. and Mansfield, T.A. 1968. Physiology of stomata. McGraw-Hill, New York. p. 55-59.

Metcalfe, C.R. 1960. Anatomy of Monocotyledons I. Gramineae. Clarendon Press, Oxford.

Mondal, M.M.A., Islam, A.F.M.S. and Siddique, M.A. 2005. Performance of 17 modern transplant aman cultivars in the northern region of Bangladesh. Bangladesh J. Bot., 21: 225-231.

Ohsuni, A., Kanemura, T., Homma, K., Horie, T. and Shiraiwa, T. 2007. Genotypic variation of stomatal conductance in relation to stomatal density and length in rice (Oryza sativa L.). Plant Prod. Sci., 10: 322-328.

Pruneddu, G. and Spanu, A. 2001. Varietal comparison of rice in Sardinia. Informatore-Agraria., 57: 47-49

Sarwar, A.K.M. Golam and Ali, M.A. 1998. Variation of panicle structure in different rice cultivars. Progress. Agric., 9: 195-199.

Sarwar, A.K.M. Golam and Ali, M.A. 2002. Studies on the leaf epidermis of rice (Oryza sativa L.). Indian J. Agric. Res., 36: 24-28.

Srivastava, G.K. and Tripathi, R.S. 1998. Response of hybrid and composition rice to number of seedlings and planting geometry. Ann. Agric. Res., 19: 235-236.

Tsunoda, S. and Fukoshima, M.T. 1986. Leaf properties related to the photosynthetic response to drought in upland and lowland varieties. Ann. Bot., 58: 531-539.

Yang, W., Peng, S., Laza, R.C., Visperas, R.M. and Dionisio-Sese, M.L. 2007. Grain yield and yield attributes of new plant type and hybrid rice. Crop Sci., 47: 1393-1400.

Yousufzai, M.-N.K., Siddiqui, K.A. and Soomro, A.Q. 2009. Flag leaf stomatal frequency and its interrelationship with yield and yield components in wheat (Triticum aestivum L.). Pak. J. Bot., 41: 663-666. 